\title{
MATERNAL SERUM MARKERS IN SECOND-TRIMESTER OLIGOHYDRAMNIOS
}

\author{
FRANS J. LOS*, ADRIANA M. HAGENAARS $\dagger$, TITIA E. COHEN-OVERBEEK $\ddagger$ AND HENDRIK W. P. QUARTERO $\ddagger$ \\ *Department of Clinical Genetics, University Hospital Dijkzigt, Erasmus University, Rotterdam, The Netherlands; \\ $\dagger$ Unit of Teratology, Endocrinology and Perinatal Screening, National Institute of Public Health and Environmental \\ Protection, Bilthoven. The Netherlands; $\ddagger$ Department of Obstetrics and Gynaecology, University Hospital Dijkzigt, \\ Erasmus University, Rotterdam, The Netherlands
}

Received 8 July 1993

Revised 5 November 1993

Accepted 22 November 1993

\begin{abstract}
SUMMARY
The levels of the maternal serum markers alpha-fetoprotein (AFP), human chorionic gonadotrophin (hCG), and unconjugated oestriol $\left(\mathrm{uE}_{3}\right)$ in 35 pregnant women with early second-trimester oligohydramnios differed from those in a reference population of 1699 singleton pregnancies. Maternal serum AFP levels above the 95 th centile of the population distribution were observed in 80 per cent $(16 / 20)$ of oligohydramnios cases with a normal fetus and in only 20 per cent (3/15) of the cases with a fetus displaying urogenital tract malformations. Elevated levels of hCG (above the 95 th centile) and decreased levels of $\mathrm{uE}_{3}$ (below the fifth centile) were encountered in 26 per cent $(9 / 35)$ and 17 per cent $(6 / 35)$ of the women, irrespective of the fetal condition. The abnormal profile of the serum markers in early second-trimester oligohydramnios resulted in 57 per cent (20 out of 35) of screen-positive cases for either fetal Down's syndrome or neural tube defects, compared with 8.4 per cent (143 out of 1699) in the reference population.
\end{abstract}

KEY wORDS - Second-trimester oligohydramnios, alpha-fetoprotein, human chorionic gonadotrophin, unconjugated oestriol, maternal serum.

\section{INTRODUCTION}

The simultaneous measurement of maternal serum alpha-fetoprotein (AFP), human chorionic gonadotrophin (hCG), and unconjugated oestriol $\left(\mathrm{uE}_{3}\right)$ concentrations is used for second-trimester screening for fetal Down's syndrome (Wald et al., 1992; Haddow et al., 1992; Cheng et al., 1993). Apart from fetal chromosomal abnormalities, adverse pregnancy outcome and various complications of pregnancy are associated with abnormal concentrations of these serum markers (Beekhuis et al., 1992; Cuckle et al., 1992). In early secondtrimester oligohydramnios, usually raised maternal serum AFP levels are encountered (Dyer et al., 1987; Richards et al., 1988; Los et al., 1992). The

Addressee for correspondence: F. J. Los, $\mathrm{PhD}$, Department of Clinical Genetics, University Hospital Dijkzigt, Erasmus University, P.O. Box 1738, 3000 DR Rotterdam, The Netherlands.

CCC 0197-3851/94/070565-04

(C) 1994 by John Wiley \& Sons, Ltd. rise of the maternal serum AFP levels in this condition has been shown to be of amniotic fluid origin (Los et al., 1992). Since placental insufficiency has been established in a significant number of oligohydramnios patients (Hackett et al., 1987), we subjected stored serum samples of oligohydramnios patients to additional measurement of $\mathrm{hCG}$ and $\mathrm{uE}_{3}$, originating from the placenta and the feto-placental unit, respectively (Hay, 1988; Canick et al., 1988), in order to study the profile of the placental markers in oligohydramnios. The scores of the three markers were introduced in the software package 'alpha' for risk estimates for fetal Down's syndrome and neural tube defects.

\section{MATERIAL AND METHODS}

Thirty-nine patients with second-trimester oligohydramnios between 15 and 20 weeks of gestational age were detected in a 4-year period among 
Table I-Fetal diagnosis in oligohydramnios patients: (i) oligohydramnios with associated fetal malformations (oligo + ), and (ii) oligohydramnios without associated fetal malformations (oligo -)

\begin{tabular}{lrc}
\hline Group & $N$ & Fetal diagnosis \\
\hline Oligo+ & 6 & Syndromes featuring bilateral renal agenesis \\
& 5 & Obstructive uropathy due to urethral obstruction \\
& 2 & Chromosomal abnormalities with a.o. renal agenesis/dysplasia \\
& & - unbalanced translocation (8;11) mat resulting in trisomy 11 (q21 $\rightarrow$ qter) \\
& 1 & 69,XXX \\
Oligo - & 1 & Multicystic kidney disease IIB \\
& 14 & Unilateral renal agenesis/contralateral renal dysplasia \\
& 6 & No malformations; normal growth \\
& & No malformations; growth retardation \\
\hline
\end{tabular}

a.o. = amongst others.

5000 pregnant women referred to us for ultrasound evaluation. In 35 of them, it was possible to obtain a serum sample with informed consent. The serum samples were stored at $-80^{\circ} \mathrm{C}$ until assay and underwent only two thawing/freezing procedures for this investigation. The technique of ultrasound investigation has been described in detail before (Los et al., 1992). The diagnosis of oligohydramnios was established when the largest and nearly always the only pocket of amniotic fluid measured up to $2 \mathrm{~cm}$ (Chamberlain et al., 1984). The reference population consisted of 1699 women with singleton pregnancies and ultrasonographically determined gestational ages between 15 and 20 weeks. From various hospitals the serum samples of these women had been submitted for measurement of AFP, hCG, and $\mathrm{uE}_{3}$ concentrations, without a thawing/freezing procedure.

AFP, hCG, and $\mathrm{uE}_{3}$ were assayed with the Amerlex $M$ second-trimester radioimmunoassay (RIA) kits for AFP, hCG, and free oestriol (Amersham). All concentrations were expressed as multiples of the median values (MoM) of the reference population for the respective week of gestation.

Risk calculations for fetal Down's syndrome and fetal neural tube defects were performed with the software package 'alpha', based on maternal age and the trivariate Gaussian distribution of log AFP, $\log h C G$, and linear $\mathrm{uE}_{3}$ concentrations (Wald et al., 1988). Cut-off points for a positive test were taken as a risk of 1:250 or higher for fetal Down's syndrome and an AFP level at or exceeding $2.5 \mathrm{MoM}$.
Statistical analysis allowed for the use of parametric tests since the serum marker levels have been shown to fit $(\log )$ Gaussian distributions (Cuckle et al., 1987; Wald et al., 1988; Crossley et al., 1993).

\section{RESULTS}

The oligohydramnios cases consisted of 35 patients (the group oligo \pm ); 15 displayed associated fetal malformations on ultrasound investigation (the group oligo+), whereas 20 patients had no fetal malformations except intrauterine growth retardation in six cases (the group oligo - ; Table I). Autopsy of the fetus confirmed the previous ultrasound diagnosis in 31 cases; in two cases no autopsy was available, and in the remaining two cases a live infant was born. The levels of AFP, $\mathrm{hCG}$, and $\mathrm{uE}_{3}$ in the groups oligo + and oligo are presented in Fig. 1 and Table II. The median AFP level in both oligohydramnios groups was raised, compared with that in the reference population, and was higher in the group oligo - than in the group oligot. AFP levels above the 95th centile were observed in 16 of the 20 [80 per cent; 95 per cent confidence interval (CI) 56.3-94.3 per cent] women of the group oligo - , and in only 3 of 15 ( 20 per cent; 95 per cent CI $4 \cdot 3-48 \cdot 1$ per cent) women in the group oligo + . The median hCG level in the group oligo \pm was raised and the distribution of values was wide with a high proportion of values above the 95 th centile $(9 / 35 ; 25 \cdot 7$ per cent; 95 per cent $\mathrm{CI} 12 \cdot 5-43 \cdot 3$ per cent). 


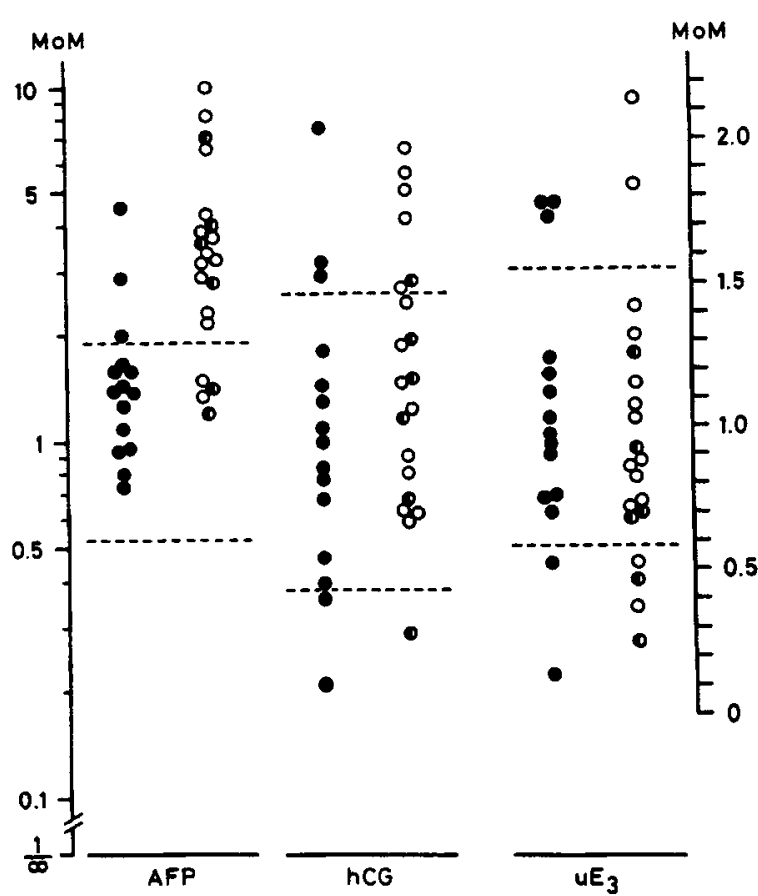

Fig. 1-Levels (in MoM) of AFP (log scale), hCG (log scale), and $\mathrm{uE}_{3}$ (linear scale) in 35 patients with second-trimester oligohydramnios. 0,0 denote patients with abnormal, normal, and normal but growth-retarded fetuses, respectively. The fifth and 95th centiles of each serum marker in the reference population are indicated

Median $\mathrm{uE}_{3}$ levels were unremarkable, but the distribution was also wide with a significant proportion of values below the fifth centile $(6 / 35,17 \cdot 1$ per cent; 95 per cent CI 6.6-33.7 per cent). In 57 per cent of the cases of oligohydramnios (20/35) a screen-positive result was obtained, either for fetal Down's syndrome or for neural tube defects, compared with 8.4 per cent of the cases (143/1699) of the reference population.

\section{DISCUSSION}

Raised maternal serum AFP levels in secondtrimester oligohydramnios are mainly associated with the presence of a normal fetus, and originate from the diminished amniotic fluid compartment (Los et al., 1992). In the 15 cases of oligohydramnios with associated fetal malformations, a renal or a post-renal fetal anuria/oliguria was present. An increased AFP transfer from the amniotic fluid compartment towards the maternal compartment, modulated by the presence or absence of fetal diuresis, explains the distinct distributions of AFP levels in-between the groups oligo + and oligo - , and between these groups and the reference population.

The concentrations of hCG show a higher median level and a wider distribution of values in the oligohydramnios patients than in the reference population, resulting in an increased number of elevated levels, known to be associated with placental pathology (Bogart et al., 1987; Hay, 1988; Beekhuis et al., 1992). The $\mathrm{uE}_{3}$ distribution in oligohydramnios shows a normal median level but a wider distribution of values than that in the reference population resulting in a significant number of decreased levels. Decreased $\mathrm{uE}_{3}$ levels are, at least in the third trimester of pregnancy, associated with reduced placental function (Chard et al., 1985; Perry et al., 1986).

Table II-AFP, hCG, and $\mathrm{uE}_{3}$ levels in the reference population and in the oligohydramnios groups. NS = statistically not significant $(P>0.05$, two-tailed $)$

\begin{tabular}{|c|c|c|c|c|}
\hline Group & $N$ & Serum marker & Median (MoM) & $t$-test \\
\hline Population & 1699 & AFP & 0.98 & \\
\hline Oligo+ & 15 & AFP & $1 \cdot 44$ & $\begin{array}{c}t=4.37 \\
P<0.001\end{array}$ \\
\hline $\begin{array}{l}\text { Oligo-- } \\
\text { Population }\end{array}$ & $\begin{array}{r}20 \\
1699\end{array}$ & $\begin{array}{l}\text { AFP } \\
\text { hCG }\end{array}$ & $\begin{array}{l}3 \cdot 28 \\
1.00\end{array}$ & \\
\hline Oligo + & 15 & hCG & 1.03 & NS \\
\hline Oligo - & 20 & $\mathrm{hCG}$ & 1.53 & \\
\hline Oligo \pm & 35 & $\mathrm{hCG}$ & $1 \cdot 30$ & \\
\hline Population & 1699 & $\mathrm{uE}_{3}$ & 1.02 & \\
\hline Oligo+ & 15 & $\mathrm{uE}_{3}$ & 1.04 & NS \\
\hline Oligo - & 20 & $\mathrm{uE}_{3}$ & 0.95 & \\
\hline Oligo \pm & 35 & $\overrightarrow{u E_{3}}$ & 0.99 & \\
\hline
\end{tabular}


Early second-trimester oligohydramnios represents a serious complication of pregnancy associated with an abnormal profile of the serum markers AFP, hCG, and $\mathrm{uE}_{3}$, resulting in a significant increased percentage ( 57 per cent) of screenpositive cases for fetal neural tube defects and/or Down's syndrome.

\section{ACKNOWLEDGEMENTS}

We are grateful to Mrs Jolanda van Deursen and Mrs Jacqueline du Parent for preparing the manuscript. We thank all the gynaecologists who referred their oligohydramnios patients to us and who submitted serum samples of their patients, especially the Department of Obstetrics and Gynaecology, State University Hospital, Utrecht, The Netherlands.

\section{REFERENCES}

Beekhuis, J.R., van Lith, J.M.M., de Wolf, B.T.H.M., Mantingh, A. (1992). Increased maternal serum alpha-fetoproteiien and human chorionic gonadotropin in compromised pregnancies other than for neural tube defects or Down syndrome, Prenat. Diagn., 12, 643-647.

Bogart, M.H., Pandian, M.R., Jones, O.W. (1987). Abnormal maternal serum chorionic gonadotropin levels in pregnancies with fetal chromosome abnormalities, Prenat. Diagn., 7, 623-630.

Canick, J.A., Knight, G.J., Palomaki, G.E., Haddow, J.E., Cuckle, H.S., Wald, N.J. (1988). Low second trimester maternal serum unconjugated oestriol in pregnancies with Down's syndrome, Br. J. Obstet. Gynaecol., 95, 330-333.

Chamberlain, P.F., Manning, F.A., Morrison, I., Harman, C.R., Lange, I.R. (1984). Ultrasound evaluation of amniotic fluid volume. I. The relationship of marginal and decreased amniotic fluid volumes to perinatal outcome, Am. J. Obstet. Gynecol, 150, 245-249.

Chard, T., Sturdee, J., Cockrill, B., Obiekwe, B.C. (1985). Which is the best placental function test? A comparison of placental lactogen and unconjugated oestriol in the prediction of intrauterine growth retardation, Eur. J. Obstet. Gynecol. Reprod. Biol., 19, 13-17.

Cheng, E.Y., Luthy, D.A., Zebelman, A.M., Williams, M.A., Lieppman, R.E., Hickok, D.E. (1993). A prospective evaluation of a second-trimester screening test for fetal Down syndrome using maternal serum alpha-fetoprotein, hCG, and unconjugated estriol, Obstet. Gynecol, , 81, 72-77.

Crossley, J.A., Aitken, D.A., Connor, J.M. (1993). Second-trimester unconjugated oestriol levels in maternal serum from chromosomally abnormal pregnancies using an optimal assay, Prenat. Diagn., 13, 271-280.

Cuckle, H.S., Wald, N.J., Thompson, S.G. (1987). Estimating a woman's risk of having a pregnancy associated with Down's syndrome using her age and serum alpha-fetoprotein level, Br. J. Obstet. Gynaecol., 94, $387-402$.

Cuckle, H.S., Densem, J.W., Wald, N.J. (1992). Detection of hydatidiform mole in maternal serum screening programmes for Down's syndrome, Br. J. Obstet. Gynaecol., 99, 495-497.

Dyer, S.N., Burton, B.K., Nelson, L.H. (1987). Elevated maternal serum $a$-fetoprotein levels and oligohydramnios: poor prognosis for pregnancy outcome, Am. J. Obstet. Gynecol., 157, 336-339.

Hackett, G.A., Nicolaides, K.H., Campbell, S. (1987). Doppler ultrasound assessment of fetal and uteroplacental circulations in severe second trimester oligohydramnios, Br. J. Obstet. Gynaecol., 94, 1074-1077.

Haddow, J.E., Palomaki, G.E., Knight, G.J., Williams, J., Pulkkinen, A., Canick, J.A., et al. (1992). Prenatal screening for Down's syndrome with use of maternal serum markers, $N$. Engl. J. Med., 327, 588-593.

Hay, D. L. (1988). Placental histology and the production of human choriogonadotrophin and its subunits in pregnancy, Br.J. Obstet. Gynaecol., 95, 1268-1275.

Los, F.J., Hagenaars, A.M., Marrink, J., CohenOverbeek, T.E., Gaillard, J.L.J., Brandenburg, H. (1992). Maternal serum alpha-fetoprotein levels and fetal outcome in early second-trimester oligohydramnios, Prenat. Diagn., 12, 285-292.

Perry, L., Hickson, R., Obiekwe, B.C., Chard, T. (1986). Maternal oestriol levels reflect placental function rather than foetal function, Acta Endocrinol, 111, 563-566.

Richards, D.S., Seeds, J.W., Katz, V.L., Lingley, L.H., Albright, S.G., Cefalo, R.C. (1988). Elevated maternal serum alpha-fetoprotein with oligohydramnios: ultrasound evaluation and outcome, Obstet. Gynecol., 72, 337-341.

Wald, N.J., Cuckle, H.S., Densem, J.W., Nanchahal, K., Royston, P., Chard, T., et al. (1988). Maternal serum screening for Down's syndrome in early pregnancy, Br. Med. J., 297, 883-887.

Wald, N.J., Kennard, A., Densem, J.W., Cuckle, H.S., Chard, T., Butler, L. (1992). Antenatal maternal serum screening for Down's syndrome: results of a demonstration project, Br. Med. J., 305, 391-394. 